\title{
Population Dynamics of Mustard Aphid, Lipaphis Erysimi Kalt in Various Brassica Spp.
}

\author{
Deepak Sharma ${ }^{1 *}$, Satyapal Yadav ${ }^{2}$ and Sunita Yadav ${ }^{1}$ \\ ${ }^{1}$ Department of Entomology, CCS Haryana Agricultural University, \\ Hisar-125004 (Haryana), India \\ ${ }^{2}$ Regional Research Station, CCS Haryana Agricultural University, \\ Rohtak-124004 (Haryana), India
}

*Corresponding author

\section{A B S T R A C T}

\begin{tabular}{|l|}
\hline Ke y w o r d s \\
$\begin{array}{l}\text { Aphid, Brassica, } \\
\text { population, Relative } \\
\text { humidity, Weather }\end{array}$ \\
\hline Article Info \\
\hline $\begin{array}{l}\text { Accepted: } \\
\text { 20 January } 2019 \\
\text { Available Online: } \\
\text { 10 February } 2019\end{array}$ \\
\hline
\end{tabular}

Population dynamics studies of mustard aphid, L. erysimi on three Rapeseed-mustard varieties i.e. RH 0749, HNS 0901 and BSH 1 belonging to three Brassica spp. i.e. $B$. juncea, $B$. napus and $B$. rapa revealed that mustard aphid was available in the field from $3^{\text {rd }}$ Standard metrological week (SMW) (January) to $11^{\text {th }}$ SMW (March). The peak aphid population (23.33-86.05 aphids $/ 10 \mathrm{~cm}$ main apical shoot) was recorded during $9^{\text {th }} \mathrm{SMW}$ in all Brassica species (both timely and late sown) except in BSH 1 (timely sown) in which it attained peak (31.98 aphids/10 $\mathrm{cm}$ main apical shoot) in $6^{\text {th }} \mathrm{SMW}$. The mustard aphid population had negative correlation with evening relative humidity under timely sown conditions and positive correlation with maximum temperature under late sown conditions in B. juncea (RH 0749) and B. napus (HNS 0901). While in B. rapa (BSH 1), the population of mustard aphid did not have any correlation with any of the weather parameters.

\section{Introduction}

The oilseed brassicas are the plant species belonging to the genus Brassica and family Brassicaceae. The different species are, Indian mustard (Brassica juncea (L.) Czern. $\&$ Coss.), toria (B. rapa L. var. toria), yellow sarson (B. rapa L. var. yellow sarson), brown $\operatorname{sarson}(B$. rapa $\mathrm{L}$. var. brown sarson), gobhi sarson (B. napus L.), karan rai (B. carinata Braun.) and taramira (Eruca sativa Mill.). All these crops are called rapeseed-mustard in vernacular language and are traditionally grown as the major groups of winter oilseed crops under irrigated and rain fed areas of India. India is one of the largest rapeseed mustard growing countries in the world, occupying the first position in area and second position in production after China (Khavse et al., 2014). India accounts for 19.29 per cent and 11.13 per cent of the total acreage and production of rapeseed-mustard in the world, respectively (Anonymous, 2013). Among the seven edible oilseeds cultivated in India, rapeseed-mustard contributes $28.6 \%$ in the total oilseeds production and ranks second after groundnut 
sharing $27.8 \%$ in the India's oilseed economy (Shekhawat et al., 2012). In India, during 2015-16, rapeseed and mustard were grown over an area of 5.75 million ha area with production and productivity of $6.80 \mathrm{~m}$ tonnes and $1183 \mathrm{~kg} / \mathrm{ha}$ respectively (Anonymous, 2017). Haryana is the third most important rapeseed-mustard producing state in the country with an area of 0.53 million ha, production of 0.90 million tonnes and productivity of $1721 \mathrm{Kg} / \mathrm{ha}$ (2015-2016) which is the highest in the country (Anonymous, 2017).

Insect pests are important biotic constraints that posed severe threat to mustard from germination to harvest and about 50 insect species have been found infesting the rapeseed-mustard in India (Sharma and Singh, 2010), out of which about a dozen of species are considered as major pest (Singh, 2009). Among them, the aphid species that damage rapeseed-mustard in India include $L$. erysimi, Brevicoryne brassicae L. and Myzus persicae Sulzer (Sarangdevot et al., 2006). Among these, L. erysimi referred as both the turnip and mustard aphid is one of the major limiting factors causing up to 96 per cent yield losses and 5-6 per cent reduction in oil content (Shylesha et al., 2006). Aphid sucks the cell sap from the stems, twigs buds, flowers and developing pods causing a significant loss in yield. For the efficient, economical and environmentally friendly management of the aphid, knowledge of its timing of attack in relation to weather factors is essential for timely prediction of its occurrence. It will allow growers to take timely action in an efficient manner for crop management (Chattopadhyay et al., 2005). Hence, studying population dynamics will provide an opportunity by manipulating the manageable ecological parameters in the form of planting or harvesting time adjustment, varietal selection and correct time of pesticidal application.

\section{Materials and Methods}

The present investigation was carried out during Rabi season of the year 2015-16 at Regional Research Station, Samargopalpur, Rohtak (Haryana), India. To record the population dynamics of mustard aphids, three Rapeseed-mustard varieties i.e. RH 0749, HNS 0901 and BSH 1 belonging to three Brassica spp. i.e. B. juncea, B. napus and B. rapa were grown under recommended Package of Practices (Anon. 2006) in plot size of $4.2 \times 3 \mathrm{~m}$ each with four repeats in randomized block design. Population of mustard aphid was recorded at weekly interval starting from the initial appearance to final disappearance of the pest. The number of aphids was recorded from top $10 \mathrm{~cm}$ top portion of the terminal shoot from ten randomly selected plants from each Brassica spp. in each replication. The data on weather parameters viz. temperature (maximum and minimum), relative humidity (morning and evening), sunshine hours, rainfall and rainy days were obtained from Indian Meteorological Department, Pune. The population of aphid was correlated with different weather parameters.

\section{Results and Discussion}

Under timely sown conditions, the initial appearance of the mustard aphid was found in the $5^{\text {th }}$ standard week (SMW) on RH 0749 and HNS 0901 and 3rd SMW on BSH1. The infestation continued up to $10^{\text {th }} \mathrm{SMW}$ on $\mathrm{RH}$ 0749 and HNS 0901 and $8^{\text {th }}$ SMW on BSH1. Under late sown conditions the mustard aphid infestation started in the $6^{\text {th }}$ standard week (SMW) on RH 0749 and HNS 0901 and $3^{\text {rd }}$ SMW on BSH1. The infestation continued up to $10^{\text {th }} \mathrm{SMW}$ onBSH1 and $11^{\text {th }} \mathrm{SMW}$ on RH 0749 and HNS 0901. Similar period of activity has been reported by Kumar (2015) who observed that the first appearance of mustard aphids was recorded during $4^{\text {th }}$ SMW except in B. rapa where it appeared during 
$3{ }^{\text {rd }}$ SMW. The peak activity of aphids was recorded during $7^{\text {th }}-8^{\text {th }}$ SMW on most of the genotypes. Talpur and Khuhro (2004) also observed that mustard aphid appeared on leaves during $3^{\text {rd }}$ week of January and on the inflorescences during $2^{\text {nd }}$ week of February and continued up to harvesting. Ansari et al., (2007) also observed that natural appearance of mustard aphid on Brassica germplasm occurred on $11^{\text {th }}$ January (60 DAS) and disappeared after $2^{\text {nd }}$ March (110 DAS).

In present study, the mustard aphid population increased gradually and attained its peak (23.33-86.05 aphids $/ 10 \mathrm{~cm}$ main apical shoot) during $9^{\text {th }}$ SMW in all Brassica species under both timely \& late sown crop (Table 1). During $9^{\text {th }}$ SMW, maximum temperature, minimum temperature, morning relative humidity, evening relative humidity and sunshine hours recorded were $30{ }^{\circ} \mathrm{C}, 16.4{ }^{\circ} \mathrm{C}$, $91 \%, 45 \%$ and $8.2 \mathrm{hrs}$, respectively. But in BSH1 (timely sown) it attained its peak (31.98 aphids $/ 10 \mathrm{~cm}$ main apical shoot) in $6^{\text {th }}$ SMW in which maximum temperature, minimum temperature, morning relative humidity, evening relative humidity and sunshine hours recorded were $22.6{ }^{\circ} \mathrm{C}, 9.6{ }^{\circ} \mathrm{C}$, $91 \%, 52 \%$ and $6.8 \mathrm{hrs}$, respectively. Choudhury and Pal (2009) revealed that the mustard aphid population attained peak level from $7^{\text {th }}$ to $9^{\text {th }}$ SMW. Malik and Sachan (2013) also observed that the incidence of mustard aphid reached to peak level in $8^{\text {th }}$ SMW i.e. $4^{\text {th }}$ week of February. In the present findings, the aphids disappeared after $11^{\text {th }}$ SMW ( $2^{\text {nd }}$ week of March) which may be due to the maturation of crop and onset of summer season. Singh and Singh (1994) reported that maturation of crop create net deficit in water content in plant tissues leading to food scarcity and alate formation in aphid colonies.

The correlation (r) worked out between mustard aphid population and weather parameters presented in Table 2 could not demonstrate a precise association between them. Under timely sown conditions, the aphid population had non-significant positive correlation with maximum temperature, minimum temperature and sunshine hours. Evening relative humidity showed significant negative correlation and morning relative humidity, rainfall and rainy days showed nonsignificant negative correlation with aphid population in RH 0749 and HNS 0901. In BSH 1, the aphid population had nonsignificant positive correlation with morning and evening relative humidity. Maximum temperature, minimum temperature, sunshine hours, rainfall and rainy days showed nonsignificant negative correlation with aphid population. Singh et al., (2007) also revealed that in early sown Indian mustard; the aphid population had a significant negative correlation with the evening relative humidity.

Under late sown conditions, in RH 0749 and HNS 0901, the aphid population had significant positive correlation with maximum temperature and non-significant positive correlation with minimum temperature and sunshine hours. Morning relative humidity, evening relative humidity, rainfall and rainy days showed non-significant negative correlation with aphid population. While in BSH 1, the aphid population had nonsignificant positive correlation with maximum temperature, minimum temperature and sunshine hours. Morning relative humidity, evening relative humidity, rainfall and rainy days showed non-significant negative correlation with aphid population. Rashid et al., (2009) also reported a positive effect with minimum and maximum temperature. Whereas mean relative humidity showed significantly negative effect on aphid population. Similarly, Hasan et al., (2009) observed a positive correlation of mustard aphid population with maximum Temperature and sun shine hours and negative correlation 
with relative humidity. Pramanik and Dey (2012) observed a significant positive correlation of aphid population with maximum and minimum temperature and bright sunshine hours and a significant negative correlation with average relative humidity. Malik and Sachan (2013) also revealed positive and significant correlation with maximum temperature (Fig. 1-6).

Table.1 Population dynamics of mustard aphid, L. erysimi during 2015-16, at Rohtak

\begin{tabular}{|c|c|c|c|c|c|c|c|c|c|c|c|c|c|}
\hline \multirow{3}{*}{$\begin{array}{l}\text { Standa } \\
\text { rd } \\
\text { week }\end{array}$} & \multicolumn{7}{|c|}{ Weather parameters } & \multicolumn{6}{|c|}{ *No. of aphids $/ 10 \mathrm{~cm}$ main apical shoot } \\
\hline & \multicolumn{2}{|c|}{$\begin{array}{l}\text { Temperature } \\
\left({ }^{\circ} \mathrm{C}\right)\end{array}$} & \multicolumn{2}{|c|}{$\begin{array}{l}\text { Relative } \\
\text { humidity (\%) }\end{array}$} & \multirow{2}{*}{$\begin{array}{l}\text { Sun } \\
\text { shine } \\
\text { hrs }\end{array}$} & \multirow{2}{*}{$\begin{array}{l}\text { Rain } \\
\text { fall } \\
(\mathbf{m m})\end{array}$} & \multirow[t]{2}{*}{$\begin{array}{l}\text { Rainy } \\
\text { days }\end{array}$} & \multicolumn{3}{|c|}{ Timely sown } & \multicolumn{3}{|c|}{ Late sown } \\
\hline & $\begin{array}{l}\text { Maxi } \\
\text { mum }\end{array}$ & $\begin{array}{c}\text { Minim } \\
\text { um }\end{array}$ & $\begin{array}{c}\text { Morni } \\
\text { ng }\end{array}$ & $\begin{array}{c}\text { Eveni } \\
\text { ng }\end{array}$ & & & & $\begin{array}{c}\text { RH } \\
0749\end{array}$ & $\begin{array}{l}\text { HNS } \\
0901\end{array}$ & BSH 1 & $\begin{array}{c}\text { RH } \\
\text { 0749 }\end{array}$ & $\begin{array}{l}\text { HNS } \\
0901\end{array}$ & BSH 1 \\
\hline 3 & 15.5 & 8.8 & 90 & 75 & 2.2 & 0.0 & 0 & 0.0 & 0.0 & 5.38 & 0.0 & 0.0 & 4.83 \\
\hline 4 & 17.5 & 7.7 & 97 & 66 & 4.2 & 0.0 & 0 & 0.0 & 0.0 & 16.45 & 0.0 & 0.0 & 13.73 \\
\hline 5 & 21.6 & 10.1 & 95 & 53 & 6.2 & 0.0 & 0 & 3.60 & 1.25 & 11.38 & 0.0 & 0.0 & 5.70 \\
\hline 6 & 22.6 & 9.6 & 91 & 52 & 6.8 & 0.0 & 0 & 7.90 & 4.78 & 31.98 & 3.70 & 5.03 & 16.70 \\
\hline 7 & 22.0 & 11.5 & 92 & 53 & 6.7 & 1.0 & 1 & 12.08 & 9.50 & 15.23 & 8.23 & 8.82 & 24.40 \\
\hline 8 & 26.9 & 14.2 & 94 & 45 & 7.2 & 0.0 & 0 & 15.13 & 14.68 & 8.64 & 39.08 & 31.42 & 46.18 \\
\hline 9 & 30.0 & 16.4 & 91 & 45 & 8.2 & 0.0 & 0 & 26.68 & 23.33 & 0.0 & 62.25 & 57.90 & 86.05 \\
\hline 10 & 27.9 & 16.4 & 94 & 55 & 8.3 & 22.0 & 2 & 5.56 & 4.70 & 0.0 & 11.92 & 10.98 & 10.98 \\
\hline
\end{tabular}

Table.2 Correlation of $L$. erysimi population with different weather parameters

\begin{tabular}{|l|c|c|c|c|c|c|}
\hline Weather parameters & \multicolumn{3}{|r|}{ Timely sown } & & & Late sown \\
\hline & RH0749 & HNS0901 & BSH1 & RH0749 & HNS0901 & BSH1 \\
\hline $\begin{array}{l}\text { Temperature } \\
\text { Maximum }\end{array}$ & 0.592 & 0.607 & -0.257 & $0.677 *$ & $0.667 *$ & 0.516 \\
\hline $\begin{array}{l}\text { Temperature } \\
\text { Minimum }\end{array}$ & 0.447 & 0.488 & -0.536 & 0.589 & 0.580 & 0.390 \\
\hline RH Morning & -0.283 & -0.256 & 0.099 & -0.202 & -0.233 & -0.198 \\
\hline RH evening & $-0.726 *$ & $-0.703 *$ & 0.004 & -0.652 & -0.650 & -0.599 \\
\hline Sunshine & 0.664 & 0.635 & -0.050 & 0.578 & 0.590 & 0.518 \\
\hline Rainfall & -0.090 & -0.077 & -0.108 & -0.048 & -0.046 & -0.168 \\
\hline Rainy days & -0.009 & -0.011 & -0.108 & -0.091 & -0.079 & -0.150 \\
\hline *Significant at P= 0.05 & & & & & & \\
\hline
\end{tabular}

Table.3 Multiple regression analysis between L. erysimi population and weather parameters

\begin{tabular}{|c|c|c|c|}
\hline \multirow{3}{*}{ Timely sown } & Varieties & Regression equations & $\mathbf{R}^{2}$ \\
\cline { 2 - 4 } & RH 0749 & Y $=45.11-0.67 X 1$ & 0.53 \\
\hline \multirow{2}{*}{ Late sown } & RHS 0901 0749 & Y $=39.09-0.59 X 1$ & 0.49 \\
\cline { 2 - 4 } & HNS 0901 & Y $=-53.95+2.90 X 2$ & 0.45 \\
\hline
\end{tabular}

$\mathrm{X} 1$ = Relative humidity (evening), X2 = Temperature (maximum) 
Fig.1 Population of L. erysimi in relation to weather parameters in $B$. juncea cv. RH 0749 (timely sown)

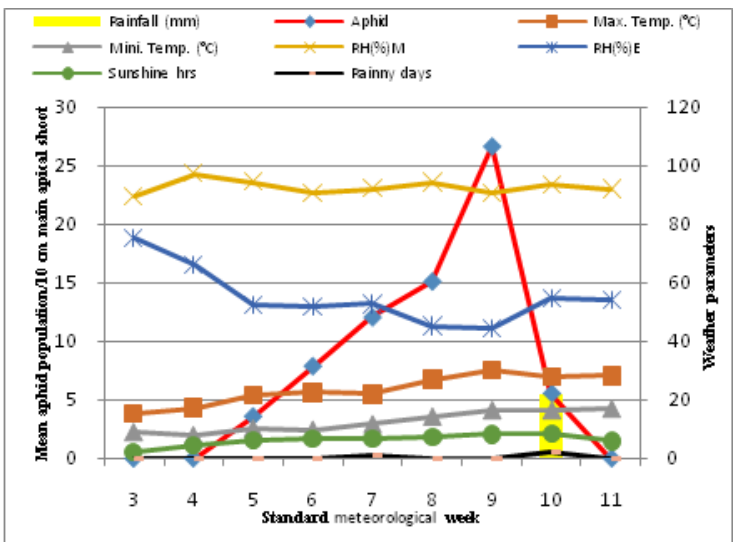

Fig.2 Population of L. erysimi in relation to weather parameters in B. napus cv. HNS 0901 (timely sown)

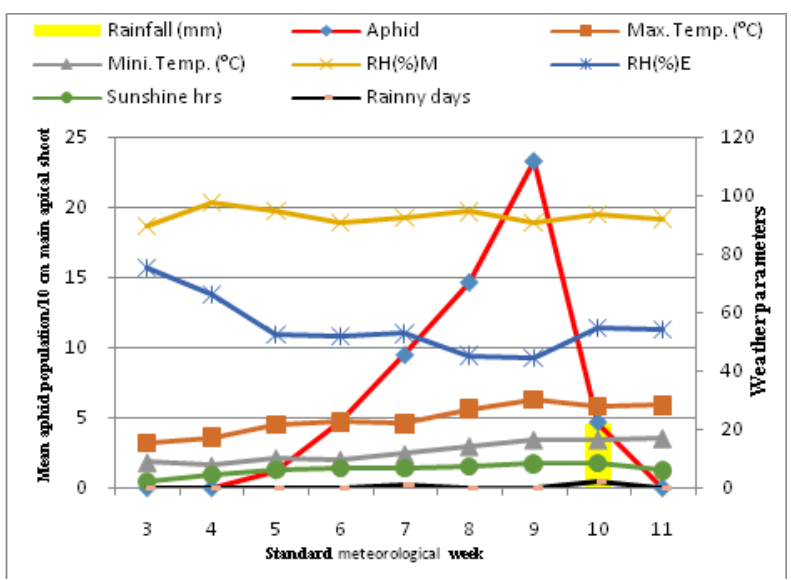

Fig.3 Population of L. erysimi in relation to weather parameters in B. rapa cv. BSH 1 (timely sown)

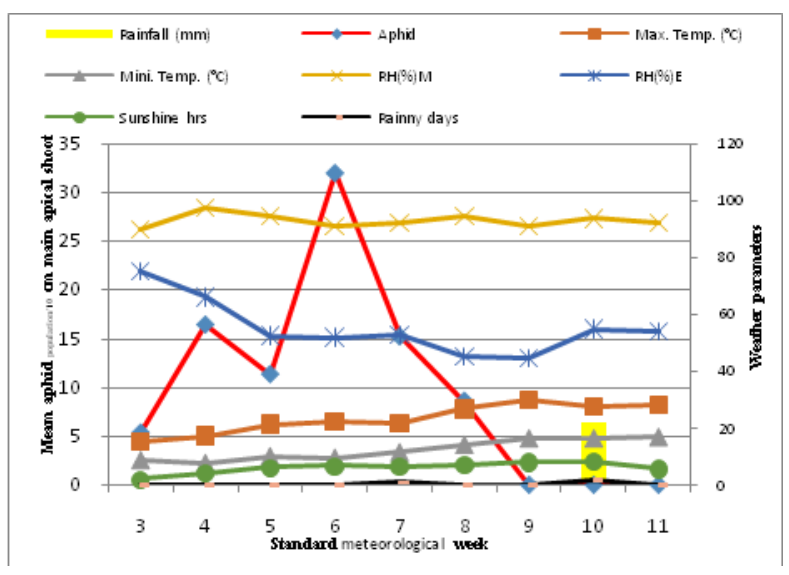


Fig.4 Population of L. erysimi in relation to weather parameters in B. juncea cv. RH 0749 (late sown)

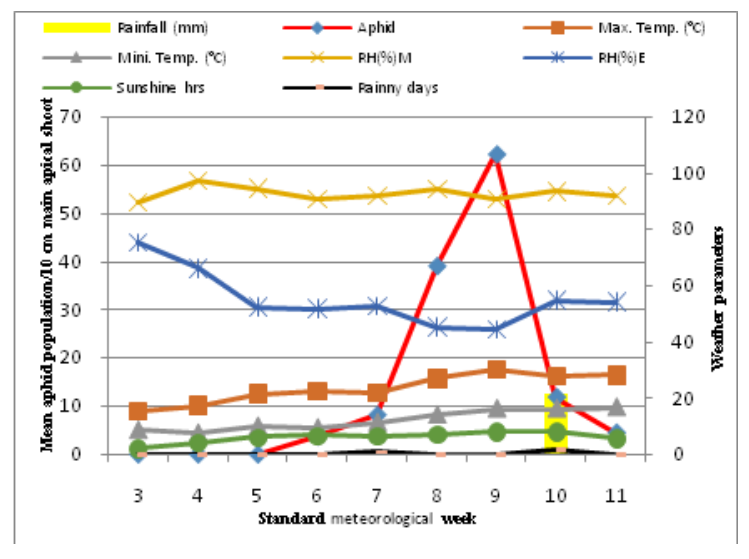

Fig.5 Population of L. erysimi in relation to weather parameters in B. napus cv. HNS 0901 (late sown)

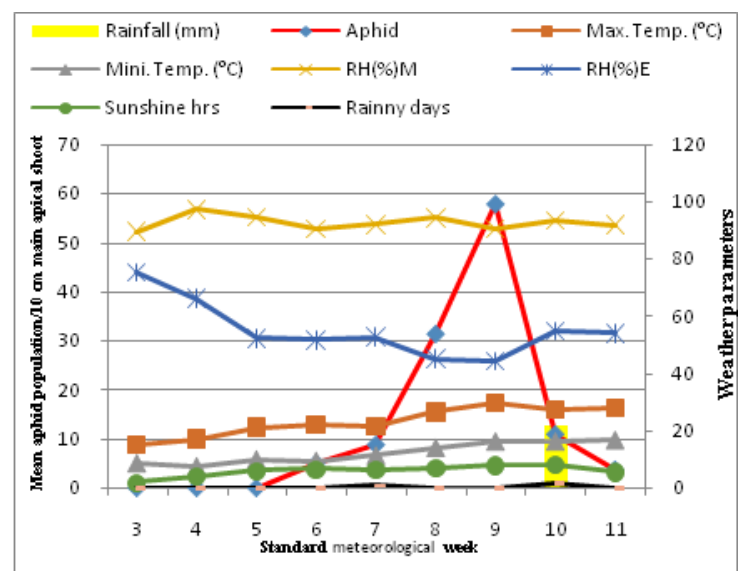

Fig.6 Population of L. erysimi in relation to weather parameters in B. rapa cv. BSH 1 (late sown)

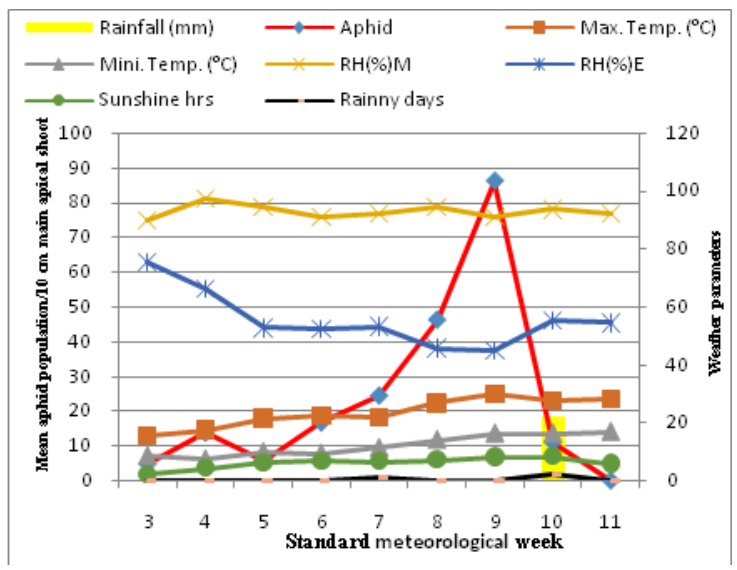


The multiple regression analysis, which explained the average relationship between $L$. erysimi and weather parameter i.e. the amount of changes in L. erysimi population per unit change in weather parameters, indicated that under timely sown conditions, evening relative humidity alone accounted for $53 \%$ variability in aphid population in RH 0749 and $49 \%$ variability in aphid population in HNS 0901. Under late sown conditions, maximum temperature accounted for $45 \%$ variability in aphid population in $\mathrm{RH} 0749$ and $44 \%$ variability in aphid population in HNS 0901 (Table 3).

\section{References}

Anonymous, 2006.Package of Practices for Rabi Crops. CCSHAU, Hisar.

Anonymous, 2013.Directorate of RapeseedMustard Research, Bharatpur, Rajasthan. www.drmr.res.in /about_rm.html

Anonymous, 2017.Agriculture statistics at a glance, 2017. Directorate of Economics and Statistics, Department of Agriculture and Cooperation, Ministry of Agriculture, Government of India. Published by Oxford University Press, New Delhi: 124-126.

Ansari, M.S., Barkat, H. and Qazi, N.A. 2007. Influence of abiotic environment on the population dynamics of mustard aphid, L. erysimi (Kalt.) on Brassica germplasm. Journal of Biological Sciences, 7(6): 993-996.

Chattopadhyay, C., Agrawal, R., Kumar, A., Singh, Y.P., Roy, S.K., Khan, S.A. and Bhar, L.M. 2005.Forecasting of L.erysimi on oilseed Brassicas in India-a case study.Journal of Crop Protection, 24: 1042-1053.

Choudhury, S. and Pal, S. 2009.Population dynamics of mustard aphid on different Brassica cultivars under terai agro-ecological conditions of West
Bengal. The Journal of Plant Protection Sciences, 1(1): 83-86.

Hasan, M.R., Ahmad, M., Rahma, M.H. and Haque, M.A. 2009. Aphid incidence and its correlation with different environmental factors. Journal of Bangladesh Agricultural University, 7: 15-18.

Khavse, R., Singh, R., Manikandan, N. and Chaudhar, J. L. 2014. Influence of temperature on rapeseed mustard yield at selected locations in Chhattisgarh state. Current World Environment, 9(3): 1034-1036.

Kumar, S. 2015. Relative abundance of turnip aphid and the associated natural enemies on oilseed Brassica genotypes. Journal of Agricultural Science and Technology, 17: 12091222.

Malik, R. and Sachan, S. K. 2013. Population buildup of mustard aphid, L. erysimi (Kalt.) on Indian mustard in relation to some abiotic factors. Progressive Agriculture, 13(1): 153-157.

Pramanik, A. and Dey, D. 2012. Influence of weather parameters on population dynamics of L.erysimi (Kaltenbach) (Hemiptera: Aphididae) and its parasitoid Diaeretiella rapae (McIntosh) (Hymenoptera: Braconidae) in mustard. Journal of Entomological Research, 36(4): 305308.

Rashid, M.H., Rahman, M.H., Matiar, Rahman, A.K.M. Mohiuddin, M. and Choudhury, M.A.R. 2009. Study on the population dynamics of mustard aphid, L. erysimi (Kalt.) in relationto weather parameters in Chittagong. Journal Soil Nature, 3(1): 20-22.

Sarangdevot, S.S. Kumar, A. and Chundawat, G.S. 2006.Field bio-efficacy of some newer insecticides against aphids infesting tomato crop.Pestology, 30(3): 20-22. 
Sharma, P. and Singh, Y.P. 2010.Directrate of Rapeseed-mustard, Indian Council of Agriculture Research, Sewar, 321303, Bharatpur (Rajasthan). Annual National Language Journal, 1: 4751.

Shekhawat, K., Rathore, S. S., Premi, O. P., Kandpal, B. K. and Chauhan, J. S., 2012.Advances in agronomic management of Indian mustard (B.juncea (L.)Crenz.Cosson): An Overview. International Journal of Agronomy, 2012: 14.

Shylesha, A. N., Azad Thakur, N.S., Pathak, K.A., Rao, K. R., Saikia, K., Surose, S., Kodandaram, N. H. and Kalaishekar, A. 2006. Integrated management of insect pest of crops in north eastern hill region. Technical Bulletin No. 19. ICAR RC for NEH Region, Umiam, p. 50.

Singh, D. and Singh, H. 1994. Correlation coefficient between abiotic biotic factors (Predator and parasitoid) and mustard aphid, L.erysimi (Kalt.) population on rapeseed-mustard. Journal of Aphidology, 8: 102-104. Singh, R., Singh, D. and Rao, V.U.M. 2007. Effect of abiotic factors on mustard Aphid, L. erysimi (Kalt.) on Indian Brassica. Indian Journal of Agricultural Research, 41: 67-70.

Singh, S.P. 2009. Insect pest management in oilseed crops. Indian farming, 58(7): 29-33.

Talpur, M.A. and Khuhro, R.D. 2004. Relative occurrence and abundance of mustard aphid, L. erysimi (Kalt.) and their predators on Rainbow and Oscar canola varieties. Journal of Asia Pacific Entomology, 7(2): 215-219.

\section{How to cite this article:}

Deepak Sharma, Satyapal Yadav and Sunita Yadav. 2019. Population Dynamics of Mustard Aphid, Lipaphis Erysimi Kalt in Various Brassica Spp. Int.J.Curr.Microbiol.App.Sci. 8(02): 2952-2959. doi: https://doi.org/10.20546/ijcmas.2019.802.344 